\title{
IN[@]VISIBLE CULTURE
}

AN ELECTRONIC JOURNAL FOR VISUAL STUDIES

\section{Cultural Studies and the Sociology of Culture}

by Janet $\mathbf{W}$ olff

(C) 1999

It is almost exactly ten years since I came to the United States from Britain, and exactly seven since I came to Rochester as Director of the Program in Visual and Cultural Studies. It is time to reflect on my complicated relationship to the discipline of sociology. And when I say that it is time, I don't mean this biographically, but more in relation to recent intellectual developments within both sociology and cultural studies, as well as to the (mostly) antagonistic relationship between the two, at least in this country. In my opinion, cultural studies at its best is sociological. And yet, in the continuing crossdisciplinary dialogue that has characterized the field of cultural studies in the decade or so of its progress in the United States, the discipline of sociology has been notably absent. At the same time, within the field of sociology, the study of culture has expanded enormously in the last twenty years among sociologists of culture, and among those who have more recently been calling themselves 'cultural sociologists,' which is not the same thing. Some of these 
sociologists have themselves adopted the term "cultural studies" to describe their work, thereby both claiming (mistakenly, as I shall suggest) to have pre-empted the newer field, and ignoring the possibility of a productive encounter with cultural studies in general and with related developments in the study of culture in the humanities. Within the past couple of years, this has begun to change, and I will be reviewing some of the newer work that begins to bridge the hitherto radical divide between sociology and cultural studies. My primary intention here is to point to the advantages that will ensue if sociologists enter into the interdisciplinary dialogue that constitutes the ever-changing field of cultural studies.

Sociologists in the Humanities

Before I came to the United States, I taught for thirteen years in a department of sociology in Britain. My geographical move also entailed an apparent change of disciplines and,given the nature of the academy in Britain and the United States, also a change of academic divisions, from the social sciences to the humanities. But the change was only apparent, except in the material sense of my institutional location. My work didn't change radically (though I hope it has developed in the past decade). I did not re-train, or take another Ph.D. Again, this biographical fact is interesting, I think, not for its own sake, but because of what it says about the organization of disciplines in Britain and the United States, and about the study of culture in the late twentieth century. There are a number of issues here. First, given my background and training in European sociology and my involvement in interdisciplinary work, I don't think many departments of sociology in this country would have been prepared to give me a home. The discipline here has remained resolutely intradisciplinary as a collective project; moreover, it has manifested a strong attachment (in some cases a growing one) to positivistic scholarship, including quantitative and 
mathematical methods. For the most part, this has also been largely true of that sub-specialization called the sociology of culture, most of whose practitioners continue to operate with untheorized and unexamined categories of social analysis. Second, new emphases have emerged in the humanities, which have invited certain sociological perspectives: new historicism, the new art history, post-colonial and feminist approaches to literature and culture, and so on. And thirdly, the success and proliferation of cultural studies in the U.S., in academic programs and in publishing has provided new opportunities for such cross-departmental moves. Given my alienation from American sociology, my life-long interest in the study of culture, and the hospitality of the humanities, my current situation makes plenty of sense. Nor is my own change of disciplinary home unique. Simon Frith, delivering his inaugural lecture as Professor of English at the University of Strathclyde, opened his talk in this way:

I ought to begin by saying that I am honoured to be giving this lecture, and indeed I am, but I have to confess that my dominant emotion is surprise. I haven't studied English formally since I did O levels, and I still find it a peculiar turn of events that I should now be a professor of English. My academic training was in sociology, and I'm tempted to treat this lecture as a sociological case study: what does it tell us about the present state of English studies that a sociologist can chair an English department? 1

Nevertheless, I suppose I have felt since coming to Rochester that my "mission" was to encourage a "sociological imagination" 2 among students in the graduate program in Rochester, a program, after all, initially founded by the collaboration of colleagues in art history, film studies, and comparative literature, only more recently including the participation of colleagues from anthropology and history. (There is no longer a department of sociology at the 
University.) I have wanted to direct them to the texts and methods of sociology and social history, and to urge them to supplement their interpretative and critical readings of visual texts with attention to the institutional and social processes of cultural production and consumption. It was a very pleasant moment for me recently when a graduate student, who came to discuss his search for a useful concept of "style," told me that he had been reading Max Weber, and said (without any prompting) before he left my office "I suppose I should look at Simmel's work." Earlier, I was delighted when a graduate student (now a faculty member at the University of Virginia) completely switched his dissertation topic and ended up writing a social and institutional (and, of course, critical) history of art education in the United States-a dissertation, by the way, that will be published next year by the University of

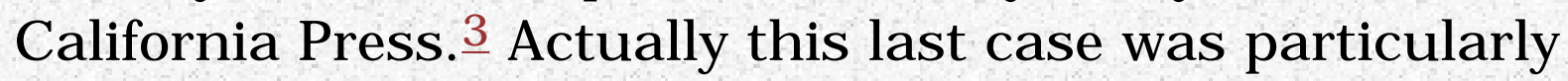
interesting because a year earlier (my first year in Rochester) this student had taken a class with me on the sociology of culture in which I had devoted quite a bit of time to the work of American sociologists. Despite my strong reservations about this work, I wanted students to recognize the importance of paying attention to institutional processes and structures in the study of culture. Some members of the class (including him) complained that this work was boring (which, actually, much of it is). Moreover, given my own criticisms of the work, which I explained, they wondered why we were spending time on it. I did not have a very good answer, except to say that nobody else was doing this kind of work well, and that I had hoped that we could read it critically in order to consider how we might indeed investigate what sociologists call "the production of culture." As it turned out, that is indeed what that graduate student did, incorporating what he found most useful in that tradition into a fine study whose intellectual influences were at the same time more wide-ranging and sophisticated.

\section{Sociology in Cultural Studies}


In this essay, I want to suggest that cultural studies can benefit from a stronger connection with sociology. A good deal of what I have to say consists of a critical review of recent developments in sociology, a discipline which for the most part has still not come to terms with the fact that, as Avery Gordon has put it, "the real itself and its ethnographic or sociological representations are ... fictions, albeit powerful ones that we do not experience as fictions but as true." $\underline{4}$ I review this work not so that I can simply dismiss it, but because, first, it retains a very high profile in the study of culture within the discipline of sociology and, second, because, as I shall show, it makes claims either to supersede or to displace cultural studies. (I should point out here, though, that there are other branches of sociology, less visible and less influential, that offer more promising approaches to the field, especially work influenced by the Frankfurt School.) 5 My critique of trends in sociology is entirely motivated by my hope for a productive encounter between cultural studies and sociology. The benefit to both fields will be the mutual recognition that-again to quote Avery Gordon ñ"the increasingly sophisticated understandings of representation and of how the social world is textually or discursively constructed still require an engagement with the social structuring practices that have long been the province of sociological inquiry." 6 What sociologists can contribute to the project of cultural analysis is a focus on institutions and social relations, as well as on the broader perspective of structured axes of social differentiation and their historical transformations-axes of class, status, gender, nationality, and ethnicity. You don't, of course, have to be a sociologist to pay attention to these analytic dimensions, and there are certainly cultural studies scholars who do just this kind of work. (Stuart Hall, Tony Bennett and Angela McRobbie come to mind.) My suggestion, rather, is that the fact that such questions constitute the raison d'être of sociology is enough reason to want sociologists to contribute to the debate about the study of culture. 
Let me give an example from my own work that illustrates how it has happened that I have been led back to my old discipline, sometimes against my own expectations. This relates to an exhibition I had planned to curate a couple of years ago. The fact that the exhibition didn't take place in the end was, for me, as interesting as the material I explored in researching my proposal. I was invited by the Whitney Museum of American Art in New York to propose an exhibition for the series "Collection in Context." These small, one-room shows have had very varied themes, and have in common only the fact that their focus is a work, or works, from the collection. Examples of exhibitions in the series include Edward Hopper in Paris, Gorky's Betrothals paintings, works from the year 1952, and the history of the Museum itself, in its various architectural homes. My proposal was to show the work of women who were active in the circle around Gertrude Vanderbilt Whitney in the twenty years leading up to the founding of the Museum in 1931, women who, though for the most part their names are now not well-known, were rather high-profile in that period and indeed up to about 1950. They had several group and one-person shows in the Whitney Studio Club, which preceded the Museum, and much of their work was owned by the Whitney on its opening, was shown in the 1931 opening exhibition, and was still prominent in a 1949 exhibition which served as a memorial to Juliana Force, Gertrude Whitney's assistant and the first director of the Museum. My first assumption was that I was engaged in the familiar feminist project of retrieval-of the re-presentation of work by women that had been "hidden from history," as a result of the by now well-known joint effects of selective art criticism, art history, and museum practices. It turned out that a sociology of cultural production served me much better than this 1970s feminist model in understanding both the contemporary success and the consequent disappearance from view of these women artists. About a third of all the work shown and bought by Force and Whitney was by women, and there is little evidence that women artists fared worse than 
men in terms of exhibition. Access to this exposure was, above all else, a function of a particular (realist and figurative) aesthetic, and membership of particular social groups and networks. These two factors were related, most of the artists having trained with the same teachers at the Art Students League in New York, and being products of some version of Ashcan-style training. Of the twenty or so women artists I considered, Katharine Schmidt, Dorothy Varian, Nan Watson, Marguerite Zorach, Peggy Bacon, and Mabel Dwight were among the founder members of the Whitney Studio Club. Varian, Bacon, Schmidt, Rosella Hartman, and Lucile Blanch, among others, lived at least part of the time, as did Juliana Force, in the artists' community in Woodstock, New York. Schmidt, Bacon, Varian, Molly Luce, and Isabel Bishop trained at the Art Students League. Schmidt worked as assistant to Juliana Force for several years. Peggy Bacon was married to the artist, Alexander Brook, who was also assistant for a while to Force. And Nan Watson was married to the critic Forbes Watson, who was Juliana Force's lover for twelve years; she also had the largest number of one-person exhibitions at the Whitney (four), and the largest number of works owned by the Museum at its opening (eight). Although there is, of course, a lot more to say about the social relations of production and exhibition, the point is that I was inevitably led to explore those social relations as I considered the incidence of work by women, and the preference for a particular aesthetic.

The ultimate demise of that aesthetic, and the eventual decision (mine and the Whitney's) not to proceed with the show, were also best understood in terms of a sociology of aesthetics. By the 1950s, the Whitney's long-standing commitment to realist art had been definitively superseded by what we might call the MoMA orthodoxy-the preference for European modernism. (The consequences for realist artists affected men as well as women; the work of Alexander Brook, Yasuo Kuniyoshi, and Guy Pène du Bois is as little known as 
that of their female counterparts in the Whitney circle.) As is well known, for example from debates and confrontations in the 1970s, the Whitney since then has operated centrally within a modernist aesthetic (and, more recently, a postmodernist one). It was, finally, an "aesthetic" judgement that undermined the possibility of the exhibition, since it was deemed that the work I planned to exhibit was not "good" enough to show. Looking back on that decision, I can now see that my acquiescence in that assessment was as much a product of my own modernist prejudices as anything. (An interesting double coda to the story is that, first, the Whitney did mount a version of that show-works on paper by the same women artists, but shown in their more marginal gallery at Champion, Connecticut-and, second, that since last year the Whitney has shown signs of taking its own figurative tradition and holdings more seriously, particularly after a major show there last year of American art as seen and curated by British curators from the Tate Gallery-as The New Yorker put it, "American art viewed through eyes used to looking at Francis Bacon and Lucian Freud."7)

\section{"Sociologically Impoverished" Cultural Studies}

My summary of this historical movement has been necessarily rather sketchy, but I hope that the point is clear. In the case of the Whitney, the rise and decline (and possible revival) of a particular aesthetic has everything to do with institutional practices and social relations. (It also has everything to do with how one might read competing visual representations, which I have not addressed in this brief summary.) I am suggesting that the sociological perspective is invaluable in directing attention to certain critical aspects in the production of culture. As I said earlier, I am well aware that it is not only sociologists who are equipped to undertake this kind of work. For example, the focus on the ideology and practices of the museum has been prominent in some important work in recent years in what is usually called "museology" or "museum 
studies," most of it done by people who are not trained in sociology. But my concern to see sociology figure more centrally in visual studies, and in cultural studies more generally, is expressed in a context in which institutional and social issues are too often ignored, and in which, as Steven Seidman has put it, the social is often "textualized." $\mathrm{8}$ A lot has been written about the "Americanization of cultural studies," much of this writing critical of the trend. 9 Some writers object to what they perceive as a depoliticization of the project in its move from Britain (and originally, of course, the Centre for Contemporary Cultural Studies at the University of Birmingham) to the United States-its detachment from social movements and its increasingly professionalized and rarefied life in the academy. Others, noting that the proliferation of cultural studies scholarship and teaching through the 1980s and 1990s has been largely (though not solely) in humanities departments, especially departments of English and Comparative Literature, identify an abandonment of the more sociological approach that understands culture in terms of axes of stratification and inequality (primarily class relations in the early years of the Birmingham Centre, but later also relations of gender and race). Cary Nelson, in one of the more impassioned critiques of this trend, describes American cultural studies as a kind of textualism-a set of ingenious, and perhaps politically-informed, new readings of texts, but readings that are ultimately ungrounded, arbitrary, and shallow. 10 In a recent article, the sociologist Michael Schudson makes a similar point through a careful and serious analysis of what he takes as a paradigmatic text in American cultural studies-Donna Haraway's "Teddy Bear Patriarchy."11 Haraway's paper, which, as Schudson says, has been much admired, and reprinted more than once, is a study of the American Museum of Natural History in New York City, and specifically its African Hall. She "reads" the African Hall, its taxidermy and its dioramas, in terms of its genesis in the 1930s, focusing on the key role of its designer, the taxidermist Carl Akeley, whose activities as explorer, hunter, and designer 
of museum "habitat groups" are discussed at some length. She also notes that the Second International Congress of Eugenics was held at the Museum in 1921 (though Akeley was not present at the time). Her interpretation of the African Hall, and of the Museum itself, is in terms of race, sex and class in New York City. (Of course I cannot do justice to her long and complex discussion here.) Schudson attacks the piece on a number of grounds. $\frac{12}{2}$ First, he challenges key factual points in her argument (arguing, for example, that the 1921 eugenics conference was not indicative of anything significant, either at the Museum or in New York in general, since, as he points out, the following conference, in 1932, attracted less than 100 people, and the Museum is, in any case, more closely associated with the anthropologist Franz Boas, who opposed the eugenics movement). Second, he takes issue with the logic of her paper, especially her use of conversion by synecdoche to link display, ideology, and politics. (The logic, briefly, is that African Hall stands for the Museum; the meaning of the Hall lies in the original plans for it; and the African Hall in 1921 or 1926 represents the unaltered meaning of the Hall.) These links, he argues, are ultimately quite arbitrary. And this is related to his third objection, which is that Haraway's essay is a study in interpretation whose superficial use of sociology allows her to ignore "how real people read museums" and "what meaning actual visitors take from African Hall or the museum generally." 13 Here, I think, he is not insisting on ethnographic studies of visitors, but rather on the careful historical and social placement of the moments and artifacts she selects for analysis. (He offers a parodic equivalent to this kind of reasoning, in which New York University is essentially fascist-a logic which works through synecdoche whereby the Elmer Holmes Bobst Library stands for the University, and its architect, Philip Johnson, at one time a fascist sympathizer, stands for the Library) $\underline{14}$ 
Schudson's general point is that contemporary cultural studies is "sociologically impoverished," to its detriment. Although he is not himself particularly devoted to the Birmingham tradition in his own work, which is in the field of media studies, he concludes with the prediction that "the works of cultural studies that will last will be the sort that follow Williams and Hoggart and Thompson, in close attention to lived experience." 15 This invocation of the "founding fathers" of British cultural studies reminds us that, despite the particular disciplinary affiliations of these writers (literature and history), Birmingham cultural studies was firmly grounded in sociology-in the texts of Weber, Marx, Mannheim, the symbolic interactionists and other sociological and ethnographic traditions. $\frac{16}{1}$ Throughout its theoretical transformations-its continuing revisions of neo-Marxist thought through the work of Althusser, Gramsci and the Frankfurt School, its radical re-thinking of its critical and conceptual framework in response to feminism and ethnic studies, and its rapprochement with

poststructuralism-"Birmingham" work retained its primary focus on the structures of social life. Let me be clear, though, that I am emphatically not recommending a return to origins, or an uncritical resumption of a pre-critical sociology. The critique of the early Birmingham model from the point of view of poststructuralist theory, first made, famously, by Rosalind Coward in an article in Screen in 1977, has been definitive. 17 In short, a sociological model that takes categories of "class" and "gender" as unproblematically given, and that reads cultural activities and products as expressions of class (and other) positions, is revealed as fundamentally determinist and theoretically naïve. As Coward shows, cultural studies must address questions of representation, signification, and the nature of the subject if it is to deal adequately with its chosen field. 18 But this poststructuralist turn in cultural studies, which renders at least problematic any talk of 'real' social relations, can be taken as opening the way to exactly that kind of cultural studies rejected by Nelson, Schudson and others- 
namely the interpretation of cultural practices undertaken without a grounding in identifiable social categories. Once we acknowledge that those social categories (class, race, gender, and so on) are themselves discursive constructs, historically changing articulations, and, ultimately, no more than heuristic devices in analysis (and, of course, in political mobilization) then where is that solidity of the social world on which a cultural studies that is not "purely textual" can depend?

In my view, this necessary re-thinking of the sociological project does not translate into license for "wild interpretation." Indeed, in the past few years there have been encouraging signs within the discipline of a determination to engage with critical theory in the humanities and in cultural studies. Two sociology journals have devoted special issues to the subject of "postmodernism"-Sociological Theory in 1991 and Theory and Society in 1992.19 A 1995 conference at the University of California in Davis, celebrating the twentieth anniversary of the journal Theory and Society, whose theme was "Interpreting Historical Change at the End of the Twentieth Century: The Challenges of the Present Age to Historical Thought and Social Theory," was notable for an interdisciplinary group of speakers, though mostly from within the social sciences. Some of the papers were informed by contemporary cultural and poststructuralist theory, and although this inevitably meant a dialogue of incomprehension (sometimes hostility) from time to time the very possibility of such a debate at a sociology conference was something new. $\underline{20}$ One speaker, the historian John Toews, had published an important article on the practice of intellectual history after the linguistic turn, which has already provoked debate about the nature of social science

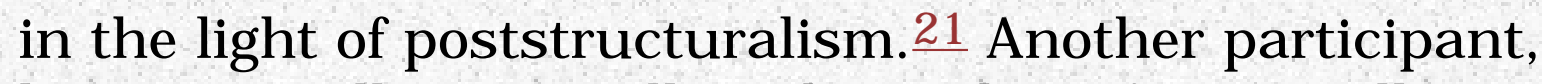
historian William Sewell, is the author of an equally important essay, which, as he summarizes it, "attempts to develop a theory of structure that restores human agency to social actors, builds the possibility of change into the concept of 
structure, and overcomes the divide between the semiotic and materialist visions of structure."22 This 1992 article, published in the mainstream American Journal of Sociology, together with his more recent work (for example, a paper on the concept of "culture" delivered at last year's ASA meetings), while not itself an example of a poststructuralist sociology, nevertheless begins the task of reconceptualizing such key sociological terms as "structure" and "culture" in ways partly informed by, and hence hospitable to, poststructuralist theory.

A conference at the University of California, Santa Barbara, organized in February 1997 by two sociologists, was designed explicitly to address the impact of cultural studies and theory in the humanities on "cultural sociology." Although not all the papers took on this particular invitation, the conference's twoparagraph rationale foregrounded the need for sociologists to take account of "new interpretive approaches in the humanities,"referring to deconstruction, anti-foundational thinking, and "sites of representation and discourse." 23 The conference was entitled "The Cultural Turn Conference," and although, as I will show in a moment, we find this term used by sociologists to mean simply a switch of focus from institutional and structural features of society to the study of culture, in this case it has the additional meaning, indicated in its published rationale, of what we might call "taking poststructuralism seriously." In this, it is used more or less synonymously with "the linguistic turn" and the "semiotic turn."

A few months ago, Blackwell published a book edited by the sociologist Elizabeth Long, and sponsored by the Sociology of Culture Section of the American Sociological Association, under the title From Sociology to Cultural Studies. Contributors include cultural studies scholars-Richard Johnson, Andrew Goodwin, Tricia Rose, George Lipsitz-as well as sociologists and anthropologists whose work is based in cultural studiesHerman Gray, George Marcus, Jon Cruz. The editor's 
introduction reviews developments in British and American cultural studies and in critical theory in the humanities, as well as in the sociology of culture, and asserts her intention, with this volume, of facilitating the dialogue across these fields. Sociologist Steven Seidman proposes the "relativization" of sociology by its encounter with cultural studies (for him, primarily the Birmingham tradition, and including its own "semiotic turn" and its turn to psychoanalysis). Such a relativized sociology would, in his opinion, have a theory of the subject and of subjectivity, a critical-moral role that rejects the traditional sociological standpoint of value-neutrality, and, as a result, "more productive ways of handling problems or concerns which are considered important by some American sociologists, e.g. relating social structure and culture, meaning and power, agency and constraint, or articulating a stronger notion of culture." $\underline{24}$ Other contributors take Elizabeth Long's invitation to contribute to the book as the opportunity to stress the other side of the relationshipcultural studies' need for a firmer sociological grounding. (Michael Schudson's critique of Haraway, which I referred to earlier, and which appears in the book, is one example of this. Richard Johnson makes the same point, in his article on "reinventing cultural studies.") 25 But of the seventeen contributors, almost all of them have, as Long points out in her introduction, "minimized territorial bickering" and have engaged seriously in the work at the intersection of sociology, the humanities, and cultural studies. 26

\section{The Sociology of Culture}

These developments, though, are occurring on the margins of the discipline of sociology (Long's book remains atypical in the field,) and I am not especially optimistic about either a more extensive re-evaluation of the field or a more widespread enthusiasm among sociologists to engage in cross-disciplinary dialogue. I want to consider in particular two branches of sociology, both relevant to the study of culture, and each 
indifferent or hostile to cultural studies. Since between them these two fields account for most of the sociological work on culture, I believe it is important to look closely at their practices and assumptions. The first is the sociology of culture, or the sociology of the arts. This sub-specialization has gone from strength to strength in the past two decades, now constituting one of the largest sections in the American Sociological Association. At last year's annual meetings, the Culture section merited five sessions and fifteen roundtables, on the basis of membership numbers. It has a quarterly newsletter, which publishes short but often important articles, and it has embarked on a series of volumes, published by Blackwell, of which the book edited by Elizabeth Long is the second. This work is represented most strongly by the study of arts organizations and institutions, known since the mid1970 s as "the production-of-culture approach." Two special issues of journals appeared with that title in 1976 and 1978 (American Behavioral Scientist and Social Research.)27 Although this is not the only model for the sociology of culture, I have chosen to discuss it since it continues to be prominent in the field. $\frac{28}{}$ Moreover, its limitations are shared by most other work within the sub-discipline. A typical study, for example, investigates publishers' decision-making criteria in two commercial publishing houses. Another looks at the role of the radio and record industries in relation to changes in the world of country music. A third studies the "gate-keeper" role of two commercial galleries in the New York art world in the 1950s. $\frac{29}{}$ These examples are all taken from the 1978 volume. But a quick review of more recent publications, and of conference presentations, confirms that twenty years later much of the work follows exactly this model. Other work has taken its departure from Howard Becker's classic essay, "Art As Collective Action," first published in 1974, and is devoted, like that essay, to the investigation of the social relations of cultural production, though in this case not necessarily within one institution-the roles of composer, performer, instrumentmaker, bureaucrat, fund-raiser, and so on. $\underline{30}$ 
As I said earlier, most sociologists of culture and the arts base their work on pre-critical, sometimes positivistic, premises. The typical methodology is to select for analysis a specific arts organization (an opera company, an art school, a gallery), identifying its social hierarchies, its decision-making processes, and, often, the aesthetic outcomes of these extraaesthetic factors (though it is rare that questions of aesthetics are permitted in this discourse, or indeed any discussion of works themselves). .31 But usually the institution is detached from both its social and its historical context, since the sociologist is dealing with the micro-social sphere. Ironically, the result is that this work is often both ahistorical and unsociological. The tenacious social-scientific commitment to "objectivity," even in qualitative (rather than quantitative) work, blocks such scholarship from addressing certain questions of interpretation, representation and subjectivity. It is instructive to compare contemporary work in museology, much of it founded on these very questions, with a recent special issue of a social science journal on the theme of "Museum Research." 32 Here are a couple of titles from the volume: "Art Museum Membership and Cultural Distinction: Relating Members' Perceptions of Prestige to Benefit Usage;" "The Effect of School-based Arts Instruction on Attendance at Museums and the Performing Arts;" and "The Impact of Experiential Variables on Patterns of Museum Attendance." (It is striking, by the way, that even Bourdieu, whose influence may be detected in a couple of these titles, can be turned into a tool for empiricism-as if he is represented simply by the tables and correlations in Distinction. 33 The complex analysis of cultural taste, in terms of class, habitus, and cultural capital, and the social critique of the Kantian aesthetic, which underlie Bourdieu's empirical work, take second place to the enthusiasm for surveys, number-crunching, and what $\mathrm{C}$. Wright Mills once denounced as "abstracted empiricism.") One of the more quantitative studies in the volume considers museum-goers' responses to ninety-four questions about their 
social, cultural, and political values and attitudes, using multiple classification analysis to explore the implications. $\underline{34}$ Here it is not so much that the statistical model seems inappropriate to the subject-matter-after all, interesting correlations can be found that way-but rather that the categories of analysis are themselves untheorized.

It is true that some sociologists of culture have begun to address issues previously ignored as "humanities" issues, and at least to consider the impact of poststructuralism. The first Blackwell volume, edited by Diana Crane and published in 1994, starts with an editor's introduction that at least mentions such theoretical perspectives. And yet Crane's very formulations make it clear that she has not got the point. For instance:

French theories, such as semiotics and poststructuralism, have inspired a greater interest in explicit or recorded culture. These theories are concerned with the ways in which texts can shape human behavior and can be used as a source of power by elites. $\underline{35}$

Or:

The change in worldview of which postmodernism is a symptom has increased the salience of cultural issues throughout the discipline. Specifically, the emphasis on predictability, coherence, and consistency which underlies the sociological method in most fields is being undermined by a new perspective which views culture as unpredictable, incoherent, and inconsistent. $\underline{36}$

One can find other examples of such awkward, and fundamentally misunderstood, references to theory in the work of several of the contributors to the volume. The fact that the editor and three of the contributors cite a famous article by Ann Swidler, which has had the status of a classic 
theoretical statement of the sociology of culture since its publication in 1986, and which recommends conceptualizing culture as a "tool kit," used by people in constructing "strategies for action," is another indication of the lingering

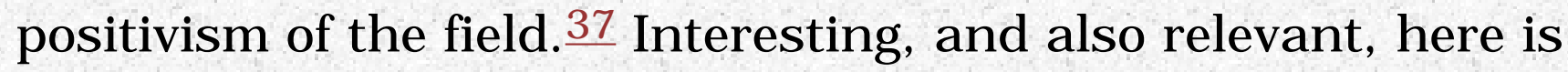
a survey of sociology of culture syllabi undertaken by Diana Crane for the ASA in 1995, which concluded that, though postmodernism and structuralism/semiotics do appear as categories on some syllabi, the British cultural studies tradition "remains peripheral in the Sociology of Culture in the United States." 38 The second Blackwell volume, then, From Sociology to Cultural Studies, appears a rather radical intervention into the sub-specialization of the sociology of culture, and it will be interesting to see whether it makes a difference to on-going work in the field. The program for the 1998 ASA annual meetings, which arrived as I was writing this lecture, does not indicate much of a change in orientation. There is, in fact, a panel devoted to "Postmodern Social Theory" (there are 518 panels offered), but it is not connected to the Sociology of Culture Section, whose own panels appear, as far as one can tell from a list of titles, to be much the same as usual.

\section{Sociological Theory and "Cultural sociology"}

The second area of sociology which foregrounds culture is sociological theory itself-that is, the theory, or theories, of society. Here in the past couple of years the term "cultural sociology" has become prominent. But this term, and its associated reference to "the cultural turn," has nothing at all to do with language, semiotics, or poststructuralism. It describes a sociological theory whose central focus is culturehere with the broader meaning of values, beliefs, ideas, and so on, and not (as in the sociology of culture) the arts in particular. Cultural sociology, then, might be the approach employed in other sub-fileds-the sociology of law, the sociology of education, industrial sociology-that have nothing to do with 


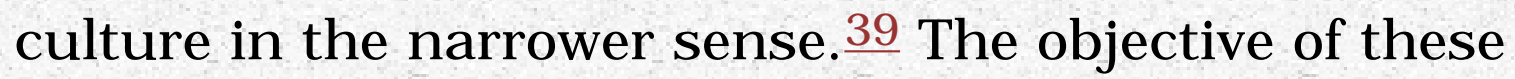
sociological theories is to emphasize the centrality of cultural aspects of everyday life, which they consider have been rendered secondary to economic, material, structural factors within the discipline. Several of these authors are fully aware of the tradition of cultural studies, but they either consider it intellectually inadequate, or maintain that anything worthwhile to be found in cultural studies was done earlier

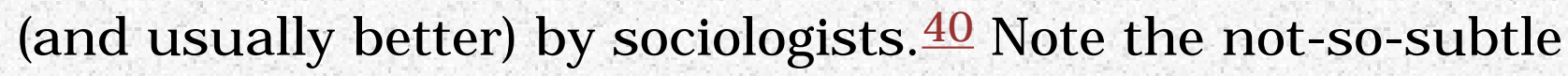
adverbs and other indicators of priority in these examples. A short article in the ASA Culture Newsletter by Michele Lamont, past Chair of the ASA section on Culture, states:

Of course, the relationship we have with cultural theory, and with theory more generally, is very different from that of academics working in Comparative Literature, English, or History departments. While sociological theory has always been at the center of our common enterprise, the interest of those scholars in 'theory'-to say nothing of their interest in power, class, etc.-has developed from their relatively recent encounter with European texts (Foucault, Ricoeur, Derrida, and others)..$\underline{41}$

And:

We need to painstakingly explain the place of theory in our field, and how issues that are being appropriated by New Historicism, New Cultural History, Cultural Studies, and 'Race Theory' have been conceptualized and studied empirically by sociologists. $\underline{42}$

Jeffrey Alexander, a prominent sociological theorist, employs the term "cultural studies," though not in a way we might recognize, in order to claim, using the same rhetorical device, that this is nothing new to sociology, but dates from the classical sociological tradition, and particularly the work of 
Emile Durkheim and his followers: "Both as theory and empirical investigation, poststructuralism and semiotic investigations more generally can be seen as elaborating one of the pathways that Durkheim's later sociology opens up." $\underline{43}$ And another example is to be found in a collection of essays on the sociological tradition known as Symbolic

Interactionism, an American tradition related to Pragmatism, and deriving from the work of John Dewey and George Herbert Mead, which emphasizes, and studies, the construction of meaning and of the "self" in social interaction. The book, incidentally, is entitled Symbolic Interactionism and Cultural Studies, though nothing in it really has anything to do with either the Birmingham tradition or cultural studies work being done within the humanities in the United States. In their introduction, the editors say:

We use the term cultural studies to refer to the classically humanistic disciplines which have lately come to use their philosophical, literary, and historical approaches to study the social construction of meaning, and other topics traditionally of interest to symbolic interactionists. $\underline{44}$

The sociological focus on the social construction of identity and of meaning does sound something like the project of a poststructuralist cultural studies. But the interest in social constructionism, as in work in the symbolic interactionist tradition, does not amount to the embrace of the radical rethinking mandated by poststructuralist and psychoanalytic theory, which exposes the constitutive role of culture and representation in the social world, as well as the discursive nature of social categories themselves. In addition, the "identity" understood in the Meadian tradition of symbolic interactionism is a socially variable, but psychically fixed entity, whose coordinates are the traditional sociological ones of social position and social role. 
Although Jeffrey Alexander appropriates the term "cultural studies" for sociology, his views on Birmingham cultural studies are clear-and totally dismissive-in a review he cowrote in 1993 of the Cultural Studies reader which came out of the 1990 Illinois conference; actually, they are immediately clear in the title of the review, which is "The British are Coming ... Again! The Hidden Agenda of 'Cultural Studies.'" 45 Like the symbolic interactionists, Alexander uses the term "cultural studies" to identify the type of sociological theory and sociological analysis he proposes. $\frac{46}{}$ In 1988, he edited a book entitled Durkheimian Sociology: Cultural Studies. The book is premised on an argument spelled out in his introduction, namely that the later work of Durkheim-especially his work on religion-provides an excellent model for contemporary sociology, given its primary focus on symbolic process. (Durkheim is, of course, primarily perceived as the sociologist who stressed "social facts," and those features of social life that are "external" to social actors; in the usual schematic history of classical sociology, he is contrasted in this with Max Weber, the begetter of "interpretative" sociology, with its focus on meaning and its methodology of Verstehen.) Alexander claims that Durkheim turned to the study of religion "because he wanted to give cultural processes more theoretical autonomy." 47 He suggests that there are parallels with the work of Saussure, Lévi-Strauss, Barthes, and Foucault, and that in some cases this is more than coincidence, but rather the unacknowledged influence of Durkheim. He goes on to review the work of certain sociologists, and some anthropologists, who have pursued Durkheim's later theory (Edward Shils, Robert Bellah, Victor Turner, Mary Douglas,) and he outlines a project for a late-Durkheimian sociology, which he calls "cultural studies." But, despite the names of structuralist and poststructuralist writers, this project is innocent of some of central theoretical insights of those writers. This is Alexander's formulation of such a sociology:

[T]he major point of departure is The Elementary Forms of 
the Religious Life, which functions as a model for explaining central processes in secular social life. The other shared emphases follow naturally from this. They concentrate, first, on what might be called motivated expressive behavior as compared with conscious strategic action. This emotionally charged action, moreover, is not seen psychologistically, but instead as the basis for ritualization. It is conceived as action organized by reference to symbolic patterns that actors-even if they have a hand in changing them-did not intentionally create. $\underline{48}$

His own chapter in the book is on Watergate and Durkheimian sociology, and he summarizes it thus:

Using Weber and Parsons, I try to connect Durkheim's later ideas to a broader theory of social structure. Rituals, I suggest, are simultaneously effects and causes of social crises; they open these liminal periods to symbolic and moral issues of the most profound kind. $\underline{49}$

The vocabulary here-"motivated expressive behavior," "the basis for ritualization," "action organized by reference to symbolic patterns," "effects and causes"-reveals, I think, a fundamental conception of culture and society that is at the same time humanist, potentially mechanistic, and grounded in the sort of "layered" model of the social world which the crudest notions of base and superstructure once gave rise to (though I should add that Alexander's hostility to Marxism is at least as energetic as his hostility to cultural studies and poststructuralist theory). In fact, some of the essays in the book are both interesting and quite sophisticated. $\frac{50}{B u t}$ Alexander's theoretical formulae, and his conception of sociology as cultural studies, continues to operate with an understanding of discrete layers-the social/institutional, and the cultural/symbolic. This is not quite culture-as-tool kit (and in fact, in the Durkheim book, he briefly criticizes 
Swidler's article) but it is not far removed from it in the end.

\section{Sociology and Cultural Studies}

I have spent some time discussing what has been called 'the cultural turn' in sociology to try to identify the grounds for a possible rapprochement with cultural studies, which, as I argued earlier, needs to work within a sociological perspective. I have pointed out that the sociology of culture (the study of the arts) has, for the most part, little interest in the critical revision of its categories of analysis. Cultural sociology, or sociological theory which foregrounds culture, on the other hand, claims both to preempt cultural studies and to improve on it. This applies to both symbolic interactionism and lateDurkheimianism. But in doing so, it retains the fatal weaknesses produced by ignoring a central aspect of cultural studies, namely a theory of representation. As Steven Seidman has put it, "American sociology, even today, has not made a semiotic turn." 51 And, in the words of Roger Silverstone, a British media studies scholar, "the sociology of culture still finds comfort in the modernist securities of classification both of approach and subject matter." $\underline{52}$ This means, amongst other things, that sociologists, while understanding the social construction of meaning and even of the social self, retain a concept of the subject as coherent, unified and stable. It also means (and this is a point made by Seidman) that they renounce the moral-critical role of cultural studies, maintaining the traditional social-scientific conception of the scholar as objective and value-neutral. And, of course, it means that sociologists cannot (yet) grasp the discursive nature of social relations and institutions. Obviously sociology, even after the "cultural turn," will not do as a model for cultural studies.

In the context of this disciplinary intransigence, I base my hope for a growing dialogue between sociology and cultural studies (and between sociology and visual studies) on two 
things: first, what seems to me to be an increasing acknowledgement within cultural studies of the importance of ethnography, of the study of social processes and institutions, and of the understanding of those structural features of cultural life that the sociological imagination has the ability to illuminate; and second, the work of some sociologists, small in number and marginalized though they might be, who have extended their view and their conceptual frameworks into new engagements with critical theory. I am not asking literary critics or art historians to become sociologists, nor, for that matter, sociologists to become cultural studies scholars. We will continue to have discipline-based interests and disciplinebased training. But cultural studies, after all, has always been the cross-disciplinary collaboration of interested scholars, and the body of work produced within that field is the product of those intellectual exchanges and influences. By now it is a cliché to say that cultural studies is not one thing-even that it cannot be defined. Stuart Hall, director of the Birmingham Centre throughout the decade of the 1970s, and still a major figure in the field, has said this, $\underline{53}$ as have the editors of various volumes of essays on cultural studies. $\frac{54}{\text { The major }}$ reason for this is that it is in the nature of cultural studies to proceed in symbiotic relationship with other disciplines. (I leave aside the question of whether or not cultural studies can itself be called a discipline.) And that relationship is, and has always been, an ad hoc affair. The particular configuration of scholars involved and, hence, disciplines represented in the multiple sites of cultural studies work has never, as far as I know, been a matter of planning, designing, and hiring.

Rather, just as was the case in Birmingham in 1964, it is the product of a group of people, with a shared interest in culture (though not necessarily a shared idea of what they mean by 'culture') beginning to meet, to discuss each other's work, to mount seminars and conferences and then, with any luck, to achieve the institutionalization of their collaborative practice in centers, programs, and teaching. Throughout the 1970s, as cultural studies programs were started in the United Kingdom 
(usually in polytechnics rather than universities), what was really striking was the great variety of intellectual combinations that emerged: literary criticism and sociology; psychology, linguistics and communication theory; literature, history and media studies. I know rather less about the 1980 s spread of cultural studies in this country, though it seems to me that a good deal of American cultural studies has been a more intra-disciplinary, literary-studies affair. Here too, though, there have been new initiatives in which crossdisciplinary collaborations have become common.

This serendipitous nature of cultural studies, which I see as nothing but a great advantage, means it continues to be an open venture. My hope, then, is that sociologists will increasingly participate in its conversations. Historians and anthropologists are already part of the collective project (including here at Rochester), but to date sociologists have, for the most part, refrained from taking part. 55 At the risk of sounding as though I am, after all, recommending a return to origins, I would point out the productive collaborations in Birmingham, which in the early years and still now have included sociologists. (In fact, the Centre for Contemporary Cultural Studies a few years ago merged with the Department of Sociology at that University.) In the United States, such conversations would both guarantee the re-sociologizing of cultural studies and ensure the long-overdue theoretical development of sociology.

Thanks to Douglas Crimp, Michael Holly, Paul Jones, Keith Moxey and Tony King for comments on an earlier draft of this paper.

\section{Notes:}

1. Simon Frith, "Literary Studies as Cultural Studies-Whose Literature? 
Whose Culture?" Critical Quarterly 43 (Spring 1998): 3-26. In England, O-level exams were taken at age sixteen.

2. The phrase was originally C. Wright Mills's. See his The Sociological Imagination (New York: Oxford University Press, 1959).

3. Howard Singerman. The book is Art Subjects: Making Artists in the American University (Berkeley: University of California Press: 1999).

4. Avery Gordon, Ghostly Matters: Haunting and the Sociological Imagination (Minneapolis: University of Minnesota Press, 1997), 11.

5. Paul Jones made this point to me, as an important corrective to what might seem to be a too generalized account of American sociology.

6. Gordon, 11 .

7. Listings, The New Yorker, 15 September 1997.

8. The term is used, for example, by Steven Seidman, "Relativizing Sociology: The Challenge of Cultural Studies," in From Sociology to Cultural Studies: New Perspectives, ed. Elizabeth Long (Oxford:

Blackwell, 1997), 37-61. Quotation from p. 41.

9. See, for example, Mike Budd, Robert M. Entman and Clay Steinman: "The Affirmative Character of U.S. Cultural Studies," Critical Studies in Mass Communication 7 (1990): 169-184; Joel Pfister, "The Americanization of Cultural Studies," reprinted in What is Cultural Studies?, ed. John Storey (London: Arnold, 1996), 287-299.

10. Cary Nelson, "Always Already Cultural Studies: Two Conferences and a Manifesto," The Journal of the Midwest Modern Language Association 14 (Spring 1991): 24-38. Nelson describes this work as a "recycled" semiotics, which he equates with textualism; however, as Keith Moxey has pointed out, however, semiotics at its best is not merely a "textual" enterprise: "Semiotics and the Social History of Art," New Literary History 22 (Autumn 1991): 985-999.

11. Donna Haraway, "Teddy Bear Patriarchy: Taxidermy in the Garden 
of Eden, New York City, 1908-1936," reprinted in Primate Visions:

Gender, Race, and Nature in the World of Modern Science (New York:

Routledge, 1989), 26-58.

12. Michael Schudson, "Cultural Studies and the Social Construction of 'Social Construction:' Notes on 'Teddy Bear Patriarchy,"' in Long, 379398.

13. Schudson, 386.

14. Ibid., 388.

15. Ibid., 395.

16. Stuart Hall reviews this intellectual trajectory in his essay "Cultural Studies and the Centre: Some Problematics and Problems," in Culture, Media, Language, ed. Stuart Hall, Dorothy Hobson, Andrew Lowe and Paul Willis (London: Hutchinson, 1980), 15-47.

17. Rosalind Coward, "Class, 'Culture' and the Social Formation," Screen 18, (Spring 1977): 75-105.

18. See also Victor Burgin's introduction to In/Different Spaces: Place and Memory in Visual Culture (Berkeley: University of California Press, 1996), 1-36. Burgin reviews the development of cultural studies in Britain, and addresses in particular the turn to semiotics and psychoanalysis by those in the field.

19. Sociological Theory 9 (Fall 1991), "Symposium on Postmodernism" and Theory and Society 21 (August 1991), "A Forum on Postmodernism." 7

20. Two examples of such an exchange were Michael Kennedy's response to a paper by Russell Jacoby, and Judith Stacey's response to a paper by Michèle Lamont, the respondent in each case challenging more traditional models of social analysis.

21. John E. Toews, "Intellectual History after the Linguistic Turn: The Autonomy of Meaning and the Irreducibility of Experience," The 
American Historical Review 92 (October 1987): 879-907. Although the article was published some time ago, Toews's invited participation at the conference indicated a new openness among some social scientists to a certain rapprochement with critical trends in the humanities.

22. William H. Sewell, Jr., "A Theory of Structure: Duality, Agency, and Transformation," American Journal of Sociology 98 (July 1992): 1-29.

Quotation from p. 1.

23. Taken from the Web site for the conference at the time: culture.html at www.sscf.ucsb.edu. I should say that I didn't attend the conference, and am guessing the nature of the papers given on the basis of their titles and of the speakers' published works.

\section{Seidman, 55.}

25. Richard Johnson, "Reinventing Cultural Studies: Remembering for the Best Version," in Long, 451-488.

26. Long, 1.

27. "The Production of Culture" special issue of American Behavioral Scientist 19 (July/August 1976) (re-published that year by Sage Publications Ltd., edited by Richard A. Peterseon) and "The Production of Culture" special issue of Social Research, 45 (Summer 1978).

28. See for example Richard A. Peterson, "Culture Studies through the Production Perspective: Progress and Prospects," in The Sociology of Culture: Emerging Theoretical Perspectives, ed. Diana Crane (Oxford, UK and Cambridge, Mass: Blackwell, 1994), 163-189.

29. Essays by Walter W. Powell, Richard A. Peterson, and Marcia Bystryn in Social Research 45 (Summer 1978).

30. Howard S. Becker, "Art as Collective Action," American Sociological Review 39 (1974). The article was later expanded in his book, Art Worlds (Berkeley: University of California Press, 1982).

31. I have written at greater length about these characteristics of U.S. 
sociology of culture. See for example The Social Production of Art (London: Macmillan, 1993), Chapter 2.

32. "Museum Research," special issue of Poetics: Journal of Empirical Research on Literature, the Media and the Arts 24 (November 1996).

33. Pierre Bourdieu, Distinction: A Social Critique of the Judgement of Taste (London, Routledge \& Kegan Paul, 1984).

34. Paul DiMaggio, "Are Art-museum Visitors Different from Other People? The Relationship between Attendance and Social and Political Attitudes in the United States," in Poetics 24 (November 1996), 161.

35. Diane Crane, "Introduction: The Challenge of the Sociology of Culture to Sociology as a Discipline," in Crane, 1-20. Quotation from p. 5.

36. Ibid.

37. Ann Swidler, :Culture in Action: Symbols and Strategies," American Sociological Review 15 (April 1986): 273-286. I should note that sociologists like Crane and Swidler, and others committed to versions of "qualitative" sociology, would certainly object to accusations of positivism. But my point is that scientistic methodologies can prevail whatever is being studied, meanings as much as observed behavior.

38. Diana Crane, "Culture Syllabi and the Sociology of Culture: What Do Syllabi Tell Us?" Newletter of the Sociology of Culture Section of the American Sociological Association 10 (Winter 1996): 1, 6-8. Quotation from p. 7 .

39. Indeed, one session at the 1997 ASA meetings was devoted to reviews of the "return to culture" in a number of sub-specializations, under the general panel heading "The Return to Culture in American Sociology." $\uparrow$

40. Herman Gray also makes this point, in passing: "Professional mainstream theorists strongly identified with specialties like social theory and the sociology of culture hold fast to the claim that sociology 
long ago dealt with the issues and questions that now appear under the sign of cultural studies." Herman Gray: "Is Cultural Studies Inflated? The Cultural Economy of Cultural Studies in the United States," in Disciplinarity and Dissent in Cultural Studies, ed. Cary Nelson and Dilip Parameshwar Gaonkar (New York and London: Routledge, 1996), 203216. Quotation is from p. 210.

41. Michele Lamont, "Crisis or No Crisis: Culture and Theory in Sociology-The Humanities and Elsewhere," Newsletter of the Sociology of Culture Section of the American Sociological Association 6 (Spring 1992): 8-9. Quotation on p. 8, my italics.

42. Lamont, 9 , my italics.

43. Jeffrey C. Alexander, "Introduction: Durkheimian Sociology and Cultural Studies Today," in Durkheimian Sociology: Cultural Studies, ed. Jeffrey C. Alexander (Cambridge: Cambridge University Press), 1-21, my italics. Quotation from p. 6. See also Jeffrey C. Alexander and Philip Smith, "The Discourse of American Civil Society: A New Proposal for Cultural Studies," Theory and Society 22 (April 1993): 151-207.

44. Howard S. Becker and Michal M. McCall's introduction to Symbolic Interaction and Cultural Studies, ed. Howard S. Becker and Michal M. McCall (Chicago: University of Chicago Press, 1990), 1-15. Quotation from p. 4. I have italicized "lately" and "traditionally."

45. Steven Jay Sherwood, Philip Smith and Jeffrey Alexander, "The British are Coming . . . Again! The Hidden Agenda of 'Cultural studies,"' Contemporary Sociology 22 (May 1993): 370-375.

46. He uses the term interchangeably, and therefore confusingly, with the term "cultural sociology." See Jeffrey C. Alexander, "Cultural Sociology or Sociology of Culture? Towards a Strong Program," Newsletter of the Sociology of Culture Section of the American Sociological Association 10 (Spring-Summer 1996): 1, 3-5.

47. Alexander, Durkheimian Sociology, 2.

48. Ibid., 11. 
49. Ibid., 14 .

50. For example, Eric Rothenbulher's study of mass strikes as ritual and interpretation, whose discussion of the symbolic meaning of such conflict has quite a bit in common with Birmingham work on subculture. Eric Rothenbulher, "The Liminal Fight: Mass Strikes as Ritual and Interpretation," in Alexander, Durkheimian Sociology, 66-90.

\section{Seidman, 43 .}

52. Roger Silverstone, "The Power of the Ordinary: On Cultural Studies and the Sociology of Culture," Sociology 28, (November 1994): 991-1001. Quotation on p.993.

53. "Cultural studies has multiple discourses; it has a number of different histories. . . . It included many different kinds of work." Stuart Hall, "Cultural Studies and Its Theoretical Legacies," in Cultural Studies, ed. Lawrence Grossberg, Cary Nelson, and Paula Treichler (New York: Routledge, 1992), 277-286. Quotation from p. 278. Also: "Cultural studies is not one thing; it has never been one thing." Stuart Hall, "The Emergence of Cultural Studies and the Crisis of the Humanities," October 53, (1990): 11-90. Quotation from p. 11.

54. For example: "[I]t is probably impossible to agree on any essential definition or unique narrative of cultural studies." Grossberg et al., 3.

55. The University of California, Santa Barbara, is one exception to this generalization. 